\title{
Abs No: HLA-A*31:01 positive hypersensitive patient
}

\author{
Maike Lichtenfels ${ }^{1}$, John Farrell ${ }^{1}$, Monday Ogese ${ }^{1}$, Catherine Bell ${ }^{1}$, Sidonia Eckle ${ }^{2}$, James McCluskey ${ }^{2}$, Kevin Park', \\ Ana Alfirevic ${ }^{1}$, Dean Naisbitt ${ }^{1 *}$, Munir Pirmohamed ${ }^{1}$ \\ From 6th Drug Hypersensitivity Meeting (DHM 6) \\ Bern, Switzerland. 9-12 April 2014
}

\section{Background}

Hypersensitivity reactions to carbamazepine (CBZ) have been shown to be strongly associated with specific human leukocyte antigen (HLA) alleles, with carriers of the HLA alleles presenting an increased risk of developing hypersensitivity. HLA-B*15:02 was detected in almost all cases of CBZ-induced Stevens-Johnson syndrome (SJS) in patients of Han Chinese or South-East Asian ancestry, and its functional role in CBZ-induced SJS has been well characterised. HLA-A*3101 is associated with all clinical phenotypes of CBZ-induced hypersensitivity in Caucasian and Japanese patients. However, functional studies investigating the role of HLA-A*31:01 in CBZ-specific T-cell responses have not been performed. Furthermore, CBZ-specific T-cells of CD4+ and CD8+ phenotype are readily detectable in Caucasian patients, which is in stark contrast to the dominant CD8+ T-cell response in Han Chinese. In this study we therefore investigated the HLA restriction of CBZ-reactive T-cells from a HLA-A*31:01 positive CBZ hypersensitive patient, focusing on both the CD4+ and CD8+ cells.

\section{Method}

Drug-specific T-cell clones (TCC) were generated by serial dilution, and their reactivity to $\mathrm{CBZ}$ measured by proliferation assay. HLA restriction of TCC was assessed using anti-HLA antibodies as well as allogeneic HLAmismatched antigen-presenting cells (APC).

\section{Results}

Activation of CD8+ TCC could be blocked by an antiHLA class I antibody, and also when an anti-HLA A30/
A31 antibody was used. Using allogeneic HLA-A*31:01+ APC and control APC expressing common HLA-A alleles, a CBZ-specific HLA-A*31:01 dependent activation of CD8+ TCC could be demonstrated. CBZ reactivity of CD4+ TCC was restricted by HLA class II, predominantly HLA-DR and HLA-DP. CD4+ TCC proliferated in the presence of $\mathrm{CBZ}$ and $\mathrm{APC}$ expressing HLA-DRB1*04:04, an HLA class II allele known to be part of a common haplotype with HLA-A*31:01 in Caucasians. APCs expressing other HLA-DRB1 alleles were unable to stimulate a response.

\section{Conclusion}

We were able to characterise the individual HLA restriction profile of CBZ-specific CD4+ and CD8+TCC from an HLA-A*31:01+ patient. We discovered an HLA class II allele, i.e. HLA-DRB1*04:04, to be functionally important for the activation of CD4+ T-cells. The strong linkage disequilibrium between the two alleles suggests a common haplotype may contribute to the multi-clonal response seen in Caucasian patients hypersensitive to CBZ.

\section{Authors' details \\ 'University of Liverpool, MRC Centre for Drug Safety Science, UK. ${ }^{2}$ University} of Melbourne, Department of Microbiology \& Immunology, Australia.

Published: 18 July 2014

doi:10.1186/2045-7022-4-S3-P117

Cite this article as: Lichtenfels et al: Abs No: HLA-A*31:01 positive hypersensitive patient. Clinical and Translational Allergy 2014 4(Suppl 3): P117.

'University of Liverpool, MRC Centre for Drug Safety Science, UK

Full list of author information is available at the end of the article

(c) 2014 Lichtenfels et al; licensee BioMed Central Ltd. This is an Open Access article distributed under the terms of the Creative Commons Attribution License (http://creativecommons.org/licenses/by/4.0), which permits unrestricted use, distribution, and reproduction in any medium, provided the original work is properly cited. The Creative Commons Public Domain Dedication waiver (http://creativecommons.org/publicdomain/zero/1.0/) applies to the data made available in this article, unless otherwise stated. 